\title{
BANK SENTRAL DALAM SISTEM KETATANEGARAAN INDONESIA
}

\author{
Ari Wirya Dinata
}

Fakultas Hukum Universitas Indonesia

Email : ariwiryadinatas@yahoo.com

\begin{abstract}
In developing countries, governments that hold state power generally act as agents of development and social change. In carrying out this role, the government needs the support of the central bank as an institution that plays an important role in financing development. The issue that will be discussed in this paper is related to the institutional independence of the Central Bank in managing the economy of a country and its relationship with the world economy. The parameters used to measure the quality of institutional independence of the central bank can refer to: first, the authority and relationship of the central bank with the government, second, filling in the positions of central bank leadership and third, institutional finance. The conclusion that can be drawn is rearranging the institutional and independence of Bank Indonesia is the Conditio Sine Qua non, because the Indonesian banking institutions are institutions that play an important role in the monetary sector.
\end{abstract}

\section{Keywords : Central Bank; Constitutional; System}

\begin{abstract}
ABSTRAK
Di negara-negara sedang berkembang, pemerintah yang menyelenggarakan kekuasaan negara, umumnya berperan sebagai agen pembangunan dan perubahan sosial. Dalam menjalankan peranan itu, pemerintah membutuhkan dukungan bank sentral sebagai lembaga yang berperan penting dalam pembiayan pembangunan. Persoalan yang akan dibahas dalam tulisan ini yaitu terkait independensi kelembagaan Bank Sentral dalam mengelola perekonomian suatu negara dan hubungannya dengan ekonomi dunia. Adapun parameter yang digunakan untuk menakar kualitas independensi kelembagaan bank sentral dapat mengacu kepada: pertama, kewenangan dan hubungan bank sentral dengan pemerintah, kedua, pengisian jabatan pimpinan bank sentral dan ketiga, keuangan lembaga. Kesimpulan yang dapat ditarik yakni menata kembali kelembagaan dan independensi Bank Indonesia adalah Conditio Sine Qua non, karena lembaga bank Indonesia adalah lembaga yang memegang peranan yang penting dalam bidang moneter.
\end{abstract}

\section{Kata Kunci : Bank Sentral; Sistem; Konstitusi}

\section{Pendahuluan}

Salah satu muatan paling penting dari suatu undang-undang dasar (konstitusi) adalah bagaimana penyelenggaraan kekuasaan negara dapat dijalankan oleh organ-organ negara yang menjalankan kekuasaan itu. Karena organ-organ atau lembaga-lembaga negara yang menyelenggarakan kekuasaan negara merupakan sub-sistem dari keseluruhan sistem penyelenggaraan kekuasaan negara. Sehingga konstitusi yang baik adalah 
konstitusi yang memberikan pedoman yang jelas mengenai susunan, fungsi dan wewenang dari lembaga-lembaga negaranya terlebih lembaga-lembaga negara yang memiliki core kewajiban yang vital dalam kehidupan berbangsa dan bernegara.

Karena sistem penyelenggaraan kekuasaan negara adalah menyangkut mekanisme dan tata kerja antar organ-organ negara sebagai satu kesatuan yang utuh untuk menjalankan kekuasaan negara. Sistem penyelenggaraan kekuasaan negara menggambarkan secara utuh cara bekerjanya lembaga-lembaga negara yang diberi kekuasaan untuk mencapai tujuan negara. ${ }^{1}$

Banyak teori yang menjelaskan mengenai konsep bagaimana menjalankan suatu kekuasaan negara salah satunya yang disampaikan oleh Monstesquie Dalam karyanya yang terkenal "Del ' Espirit des lois" ( the spiri of laws, 1748). Montesquieu menulis bahwa despotisme (kelaliman) adalah merupakan bentuk pemerintahan yang buruk. Bentuk pemerintah yang terbaik menurutnya adala sistem kebebasan dimana warga negara memiliki hak untuk melakukan apa saja sepanjang tidak melanggar hukum. ${ }^{2}$ Namun dia juga menyadari bahwa kebebasan

1 Hamdan Zoelva, Sistem Penyelenggaraan Kekuasaan Negara Menurut Undang-Undang Dasar Negara Republik Indonesia 1945 dalam perubahan UUD 1945 Tahun 1999-2002 ( dalam bahasa akademik, bukan politik), (Jakarta: KonPress, 2007) hlm 223-224

${ }^{2}$ Moh Mahfud, Dasar dan Struktur Ketatanegaraan Indonesia Edisi Revisi, (Jakarta:Rineka Cipta, 2001) $\operatorname{hlm} 73$ pun dapat mengancam demokrasi. Untuk itu pembagian kekuasaan (separation of power ${ }^{3}$ ) diperlukan. ${ }^{4}$ Konsep pentingnya kekuasaan dipisah dan dipecah dalam berbagai lembaga/organ agar tidak terjadi tirani dan monopoli kekuasaan oleh satu lembaga/organ saja. Keadaan demikianpun telah diutarakan oleh Lord Acton dalam kredonya " Power tends to corrupt, absolute power corrupts absolutely. Bahwa kekuasaan itu cenderung disalahgunakan dan kekuasaan yang tanpa adanya penyimbang sudah pasti akan disalahgunakan.

Namun begitu konsep pembagian kekuasaan ini memiliki makna yang berbedabeda di berbagai negara. Sebagai contoh makna pembagian kekuasaan menurut Judge Phineas M Mojapelo dapat dilihat dalam 3 kategori $^{5}$ :

\section{That the same person should not} form part of more than one of the three organs of government, for

\footnotetext{
${ }^{3}$ Separation of power diartikan oleh O Hood Philips dan yang lainnya sebagai the distribution of the various powers of governmet among different organs. Dengan perkataan lain, kata separation of power diidentikan dengan distribution of power. Oleh karena itu, istilah-istilah separation of powers, division of powers, distribution of powers, dan demikian pula istilah pemisahan kekuasaan dan pembagian kekuasaan, sebenarnya mempunyai arti yang sama saja. Tergantung konteks pengertian yang dianut. Lebih lanjut baca : Jimly Asshiddiqqie, Pengantar Hukum Tata Negara, (Jakarta: Rajawali Press, 2013) hlm 288

4 Abdy Yuhana, Sisem Ketatanegaran di Indonesia Pasca Peubahan UUD 1945, (Bandung: Fokusmedia, 2007) hlm 43

${ }^{5}$ Phineas M Mojapelo, The Doctrine of Separation of Powers, a South African Perspective), disampaikan dlaam The Middle Temple South Africa Conference 2012 hlm 37
} 
example, that minister should not sit in parliament;

2. That one organ of government should not control or interfere with the work of another, for example, that executive should not interfere in judicial decisions;

3. That one organ of government should not exercise the functions of another, for example, that ministers should not have legislative powers

Perdebatan tentang posisi kelembagaan bank sentral telah lama terjadi, sebab apabila mengacu kepada konsep pembagian kekuasaan yang dipaparkan oleh John Locke maupun Montesqqieu maka agak sulit untuk meng-kategorikan kelembagaan bank sentral untuk menjadi bagian dari kekuasaan eksekutif, kekusaan legislatif ataupun kekuasaan yudikatif. Keunikan peran dan wewenang yang dimiliki oleh bank sentral maka kekuasaan bank sentral kerapkali disebutkan sebagai kekuasaan diluar dari model trias politika.

Bank sentral memiliki arti penting dalam merumuskan kebijakan ekonomi makro khususnya dibidang moneter di pelbagai negara termasuk di Indonesia, Amerika Serikat, Jerman. Bahkan dikarenakan pentingnya peran lembaga ini, sebagai contoh Gubenur, Federal Reserve Amerika Serikat, Yellen Janet. dinobatkan sebagai wanita paling berpengaruh No 1 di dunia pada tahun 2017 oleh Majalah Forbes, penyematan gelar ini tentunya sedikit banyak berkorelasi dengan posisinya yang strategis bagi perekonomian Amerika Serikat dan tentunya efek domino yang dapat ditimbulkan dari kebijakan yang dikeluarkan The Fed terhadap seluruh negara dunia yang merupakan mitra dagang dan ekonomi US. sebagai orang nomor satu di bank sentral Amerika kebijakan The Fed yang dibuat Yellen Janet membuatnya harus bekerja secara profesional dan terlepas dari campur tangan Pemerintah Amerika.

Sementara itu, di negara-negara sedang berkembang, pemerintah yang menyelenggarakan kekuasaan negara, umumnya berperan sebagai agen pembangunan dan perubahan sosial. Dalam menjalankan peranan itu, pemerintah membutuhkan dukungan bank sentral sebagai lembaga yang berperan penting dalam pembiayan pembangunan. Sebagai konsekuensinya, bank sentral selalu ditarik untuk berdekatan dengan pemerintah sebagai agen pembangunan. Salah satu fungsi bank sentral adalah sebagai bankir pemerintah. Karena itu wajar jika bank sentral harus memenuhi kebutuhan pembiayaan pembangunan yang dilakukan oleh pemerintah. Isu inilah kemudian yang mengantarkan kepada status quo independensi kelembagaan Bank Sentral apakah lembaga ini didesain sebagai bagian dari eksekutif layaknya Kementerian Keuangan, Badan pemeriksa Keuangan yang 
menangani isu ekonomi nasional atau justru dia merupakan lembaga yang berada diluar lingkar tersebut dan bekerja secara mandiri dan berdasarkan asas checks and balances saja. $^{6}$

Tapi bentuk dan sifat peranan bank sentral sebagai bankir pemerintah tersebut di negara-negara berkembang dipengaruhi oleh peranan kongkrit yang dijalankan oleh pemerintah sebagai agen pembangunan. Hal demikian dapat dipahami sebab di negara berkembang peran bank sentral tidak melulu soal menjaga stabilitas moneter tetapi juga mencangkup hal lain sebagai mitra pemerintah dalam melakukan pembangunan nasional.

Begitu pula halnya Bank Indonesia dalam Napak Tilas kelembagaan apabila di telusuri dari berdirinya bangsa ini hingga pelbagai konstitusi yang pernah berlaku bank sentral memainkan peran ganda dalam tugasnya. sehingga gejala ini menarik minat banyak pengamat asing. Mereka umumnya menyadari bahwa bank sentral di negaranegara sedang berkembang, dalam hal ini dengan melihat ke kasus Bank Indonesia, tak bisa menghindari peran kongretnya dalam ikut mengemban misi pembangunan yang digariskan oleh pemerintah dan karena itu tidak terbatas pada fungsinya sebagai penjaga stabilitas moneter melalui pengendalian uang beredar semata-mata.

${ }^{6}$ Ibid
Bahkan bank sentral dimasa-masa tertentu seringkali juga tidak bisa menghindari dari keterlibatannya dalam pembiayaan-pembiayaan proyek-proyek non pembangunan yang ditetapkan pemerintah dalam keadaan dimana sumber penerimaan negara, khususnya pajak, masih terbatas sehingga pemerintah harus melaksanakan anggaran defisit dalam anggaran penerimaan dan belanja negara yang cenderung menimbulkan tekanan inflasi dan kegoncangan-kegoncangan moneter, akibatnya peran kongretnya ini tidak sejalan dengan fungsi utamanya sebagai penjaga stabilitas moneter.

Bicara mengenai isu pokok dari sifat kelembagaan bank sentral maka sepanjang sejarah konstitusi yang pernah berlaku di Negara Indonesia, pengaturan tentang bank sentral atau yang dinamakan dengan Bank Indonesia tidak pernah secara tegas mengatur bagaimana bentuk independensi lembaga tersebut. Bahkan tersirat dalam risalah pembahasan penyusunan UndangUndang Dasar 1945 sebelum perubahan, perihal bank sentral tidak mendapatkan perhatian secara khusus dan tersendiri dalam proses penyusunan. Sehingga bisa kita lihat dalam Undang-Undang Dasar 1945 sebelum perubahan tidak satupun pasal yang menyebutkan kata bank sentral atau lembaga negara lain yang menjalankan fungsi serupa.

Terkait dengan independensi Bank Indonesia yang merupakan amanat langsung 
Undang-Undang Dasar 1945 setelah perubahan, apabila didefinisikan menurut kamus bahasa Indonesia, independensi juga diartikan merdeka, sendiri, yang berdiri sendiri, yang berjiwa bebas, atau bebas.

Sementara apabila menilik kedalam Undang-Undang Dasar 1945 hanya terdapat 4 (empat) lembaga negara yang secara tegas hanya dinyatakan menggunakan kata bebas, merdeka atau Independen dan mandiri. Keempat lembaga negara tersebut adalah Pertama, Badan Pemeriksa Keuangan dengan kata "bebas" sebagaimana termaktub dalam Pasal 23E ayat (1) Undang-Undang Dasar 1945 perubahan menyatakan “ untuk memeriksa pengelolaan dan tanggung jawab tentang keuangan negara diadakan satu Badan Pemeriksa Keuangan yang Bebas dan Mandiri.

Kedua, kekuasaan kehakiman yang terdiri dari Mahkamah Agung dan Mahkamah Konstitusi dengan kata "merdeka" sebagaimana pada Pasal 24 ayat (1) Undang-Undang Dasar 1945 perubahan yang menyebutkan “ Kekuasaan kehakiman merupakan kekuasaan yang merdeka untuk menyelenggarakan peradilan guna menegakan hukum dan keadilan”.

Ketiga, Komisi Pemilihan Umum, sebagaimana disebut dalam Pasal 22E ayat (5) UUD 1945. Selengkapnya sebagai berikut " Pemilihan umum diselenggarakan oleh suatu komisi pemilihan umum yang bersifat nasional, tetap, dan mandiri”.
Dan keempat adalah bank sentral dengan menggunakan kata "independensinya" seperti disebut dalam Pasal 23D UUD 1945. Detailnya berbunyi sebagai berikut " Negara memiliki satu bentuk bank sentral yang susunan, kedudukan, kewenangan, tanggung jawab dan independensinya diatur dengan undangundang”.

Berbeda dengan apa yang diatur terhadap Mahkamah Agung dan Mahkamah Konstitusi sebagai lembaga yang dinyatakan bersifat "mandiri" maupun Badan Pemeriksa Keuangan yang dinyatakan sebagai lembaga negara yang bersifat “ bebas”. Konstitusi setidaknya mengatur mekanisme dasar dalam pengisian jabatan hakim agung dan hakim konstitusi serta pimpinan badan pemeriksa keuangan. Padahal bank sentral yang dalam Undang-Undang Nomor 23 Tahun 1999 sebagaimana diubah dalam Undang-Undang Nomor 3 Tahun 2004 disebut lebih lanjut dengan Bank Indonesia memegang kewenangan yang sangat strategis menyangkut moneter.

Akibat tidak adanya pengaturan yang rigid mengenai proses pemilihan jabatan pimpinan BI menyebabkan jabatan yang vital ini rentan untuk ditafsir secara multi padahal posisi pimpinan BI sangatlah strategis sehingga seharusnya jauh dari politik yang pragmatis. akibat banyak penafsiran dalam proses seleksi pimpinan lembaga negara melahirkan dinamika politik dan hukum 
dalam beberapa kali proses seleksi pimpinan lembaga negara di Indonesia. Bahkan juga menjurus serta masuk pada ranah pelanggaran hukum pidana seperti halnya kasus suap agar dapat menduduki jabatan yang diinginkan. Khususnya Bank Indonesia, kasus yang melibatkan Miranda Swaray Goeltom setidaknya menjadi pelajaran dalam proses pengisian jabatan pimpinan Bank Indonesia yang membuktikan praktik jual beli jabatan. Miranda terbukti secara bersama-sama dengan Nunun Nurbaeti menyuapkan anggota Dewan Perwakilan Rakyat periode 1999-2004 untuk dapat menjadi Deputi Gubenur Senior BI pada 2004.

Persoalan independensi kelembagaan ini menjadi sangat penting, karena peran dan kewenanngannya yang sangat luar biasa dalam mengelola perekonomian suatu negara dan hubungannya dengan ekonomi dunia. Oleh sebab itu, dibutuhkan suatu independensi kelembagaan yang mumpuni. Adapun parameter yang digunakan untuk menakar kualitas independensi kelembagaan bank sentral dapat mengacu kepada: pertama, kewenangan dan hubungan bank sentral dengan pemerintah, kedua, pengisian jabatan pimpinan bank sentral dan ketiga, keuangan lembaga. Tiga parameter tersebut adalah indikator yang dapat digunakan untuk menilai sejauh apa lembaga bank sentral terlepas dari intervensi kekuasaan lain dalam menjalankan tugas dan kewajibannya.

\section{Pembahasan}

\section{Selayang Pandang Bank Sentral}

Bank sentral, dalam pengertian umum adalah sebuah lembaga yang diserahi tugas untuk mengontrol sistem keuangan dan perbankan. Guna untuk menjalankan peranannya itu, bank sentral umumnya diberi monopoli untuk mengeluarkan uang dan wewenang pregoratif untuk mengatur jumlah uang yang beredar. Disamping itu, bank sentral juga diberi fungsi dan wewenang untuk membina dan mengawasi kegiatan perbankan sebagai perantaraan keuangan (financial intermediary). ${ }^{7}$ Tidak hanya berwenang mencetak uang dan mengatur jumlah uang yang beredar dimasyarakat tetapi bank sentral juga memiliki peran lainnya yang berhubungan dengan arsitektur ekonomi suatu negara. Adapun peran lainnya tersebut dijelaskan oleh Paul Smith sebagai berikut:

Central bank plays many roles. They are established and controlled by the political authorities and their functions and responsibilities differ widely from country to country. The central bank nearly always has responsibility for the countrry's currency. It may or may not have effective control over the reserves of the country's banking system. The central bank is likely to be the government's banker and may even

\footnotetext{
${ }^{7}$ Maqdir Ismail, Bank Indonesia dalam Perdebatan Politik dan Hukum, (Yogyakarta: Navila Idea, 2005) hlm 13
} 
serve the publi directly in a variety of ways. ${ }^{8}$

Dalam menjalankan fungsinya itu, bank sentral mempunyai peranan khusus dalam sistem moneter sebagai sumber peminjaman bagi bank-bank (the banker's bank) atau dalam istilah penulis menyebutnya sebagai the mother of bank atau The Bank of Bank. Selain itu bank sentral merupakan sumber terakhir bagi bank-bank untuk mendapatkan pinjaman ketika bank yang bersangkutan sedang mengalami kesulitan likuiditas (lender of the last resort). Dalam fungsinya ini, bank sentral sekaligus juga berperan dalam mengembangkan sistem pengkreditan yang sehat.

Dalam bingkai sejarah, lembaga bank sentral dalam pengertian modern, mula-mulai berkembang di negara-negara yang sekarang berstatus industri maju, khususnya Eropa dan Amerika Utara,. Bank sentral, sebagaimana dalam bentuknya yang sekarang, telah mengalami proses evolusi yang panjang, embrio bank sebagai lembaga perantara keuangan yang fungsinya adalah memberikan kredit dan jasa-jasa dalam lalu lintas pembayaran dan peredaran uang dengan tujuan memenuhi kebutuhan kredit dengan modal sendiri dan orang

\footnotetext{
${ }^{8}$ Paul F Smith, Comparative Financial Systems, ( New York: Praeger Publisher, 1982) hlm 29
}

lain, sebenarnya sudah dikenal sejah kurang lebih 2500 tahun sebelum masehi di mesir, demikian pula pada zaman yunani purba, yunani kuno dan romawi. Tapi perbankan modern baru berkembang di Barcelona ( 1401) Genoa (1404), Venesia (1587) dan Milan ( 1593) dan kemudian berkembang ke negara-negara lain, antara lain Amsterdam (1609), dan Hamburg (1619) yang terutama melayani kebutuhan kredit perdagangan dan pinjaman kepada pemerintah. ${ }^{9}$

Sedangkan di Australia bank sentral berdiri setelah Commonwealth bank act dikeluarkan pada tahun 1911 dan bank sentral mulai beraktivitas pada pertengahan tahun 1912. Adapun kekuatan dibalik legislasi UU tersebut merupakan suatu kombinasi dari ide bank sentral yang tidak mudah dan suatu hasrat untuk memberantas dan membatasi kekuasaan uang dan menasionalisasi operasi perdagagan bank-bank. ${ }^{10}$

Semetara di Inggris kelahiran bank sentral diawali dari sejarah ketamakan bank konvensional mengelola keuangan dimana terjadi kompetensi tidak sehat antar bank dalam melakukan kegiatan keuangan sehingga menimbulkan resiko bagi para nasabah. Beberapa sangat

\footnotetext{
${ }^{9}$ Dawan Rahardjo, Bank Indonesia Dalam Kilasan Sejarah Bangsa, ( Jakarta:LP3ES, 1995) hlm 17-19

10 L.F Giblin, The Growth of A Central Bank, (Melbourne: Melbourne University Press, 1951) hlm 3
} 
tamak, mereka berspekulasi secara gambling terhadap uang nasabah secara kesepakatan yang tidak bijak. Karena kemudian bank-bank yang memiliki ketamakan tidak memiliki cadangan uang yang cukup untuk menjalankan fungsinya sehingga dapat menyebabkan krisis keuangan oleh sebab itu dibutuhkan lembaga khusus untuk mengawasi perilaku perbankan ini. $^{11}$ Mishkin mengatakan bahwa

" a central bank had to manage the blood circulation for the heart of the national economy. Because, actions taken by a central bank directly effect interest rate, the amount of credit, and the money supply. All which have direct impacts not only on financial markets but also on agregate output and inflation. ${ }^{12}$

Dari pemaparan tersebut dapat ditarik kesimpulan bahwa di dalam dunia modern dimana aktivitas orang-orang sudah sangat bergantung dengan kondisi keuangan sehingga tanggung jawab bank sentral menjadi krusial untuk pembangunan dan pertumbuhan. ${ }^{13}$ Selanjutnya, bank sentral mulai tercipta di Eropa pada paruh kedua abab ke-17 . Riskbank Swedia didirikan pada tahun 1664, diikuti oleh Bank of England

\footnotetext{
${ }^{11}$ Peter Hobday, Inside The Bank of England, (Great Britain: Priory Press, 1976) hlm 22

${ }^{12}$ Fachry Ali, Bahtiar Effendy, Umar Juoro dkk, The Politicis of Central Bank, The Position of Bank Indonesia Governor in Defending Independence, (Jakarta: LSPEU Indonesia, 2003) hlm 1

${ }^{13}$ Herbert V Prochnow, The Federal Reserve System, (New York: Harper \& Brother Publisher, 1960) hlm 26
}

ditahun 1694, lalu Bank Perancis di tahun 1800 dan Bank Belanda pada 1814. Sebelum berdirinya bank-bank sentral tersebut fungsi-fungsinya ditangani oleh bendahara kerajaan (royal treasury) atau sebuah bank komersial besar yang ditunjuk pemerintah khusus untuk itu, Bank sentral dalam coraknya yang sekarang masih merupakakn hal baru. Pada awal abad ke-20 baru ada 18 bank sentral, sedangkan pada tahun 2000 sudah ada 174 bank sentral di seluruh negara di dunia. ${ }^{14}$

Ada 2 (dua) faktor yang mendorong pembentukan bank-bank sentral awal di Eropa. Pertama, tekanan keuangan yang begitu berat akibat membiayai perang, pemerintah dibanyak negara Eropa menyadari bahwa mereka memerlukan dukungan permanen dari sejumlah bank swasta, lebih dari yang biasanya mereka terima. Melalui perundang-undangan di parlemen, pemerintah memilih bank swasta terbaik untuk dijadikan bank sentral. $^{15}$

Kedua, pemerintah menyadari perlunya penyatuan fungsi/sistem pencetakan uang, dan lembaga terbaik

\footnotetext{
${ }^{14}$ Soedradjad Djiwandono, Paul Soetopo, Sukarwan dkk, Sejarah Bank Indonesia Periode IV: 1983-1997, Bank Indonesia pada Masa Pembangunan Ekonomi dan Pola Deregulasi, (Bank Indonesia: Jakarta, 2006) hlm 2

15 Akhand Akhtar Hossain, Bank Sentral dan Kebijakan Moneter di Asia Pasifik, ( Jakarta: Rajawali Press, 2010) hlm 34
} 
yang menanganinya adalah bank sentral.

Disamping pencetakan uang, diperlukan pula suatu lembaga khusus untuk mengelola dan melindungi cadangan logam mulia milik negara sekaligus menyempurnakan sistem pembayaran nasional. Fungsi-fungsi itu pun idealmya dilakukan oleh sebuah bank sentral ${ }^{16}$

Bank sentral dalam sebuah negara berdiri dalam satu hubungan yang khusus dengan pemerintah. Sebagaimana disebutkan oleh Kisch dan Elkin "Seeing taht by its discount policy and the subsequent reaction on credit, gold reserves and note issues it control amount of purchasing power available, and is thus responsible for safeguarding the currency standar established by law. ${ }^{17}$

Hubungan yang dekat pemerintah dengan bank sentral terdengar bahwa bank sentral terindikasi melalui fakta bahwa di beberapa negara. Bank sentral menjalankan fungsi dan wewenangnya dibawah jaminan dari pemerintah. Di Swedia sebagai contoh UU nya mengatakan secara umum bahwa Riksbank diberada dibawah jaminan pemerintah. Begitupula dengan australia menyebutkan bahwa pemerintah bertanggung jawab atas semua aktivitas

\footnotetext{
${ }^{16}$ Ibid

17 Kisch dan Elkin, Central Bank A Study of Constitution of Bank Issue, with analysis of Representative Charter ( London: The Macmilan Company, 1928) hlm 16
}

keuangan yang dilakukan oleh Commonwealth Bank of Australia. Bahkan disebutkan secara jelas apabila bank sentral gagal memenuhi kewajibannya maka pemerintah dapat melakukan intervensi. ${ }^{18}$

Never forget that iw was created to serve the employer and the working man, the producer and the consumer, the importer and the exporter, the creditor and the debtor, all in the interest of the country as a whole ${ }^{19}$

2. Napak Tilas sejarah Bank Indonesia dalam bingkai Konstitusi di Indonesia

Selama pembahasan rancangan UUD 1945 dalam sidang-sidang BPUPKI ( Badan Penyelidik Usaha-Usaha Persiapan Kemerdekaan Indonesia) dan PPKI (Panitia Persiapan Kemerdekaan Indonesia), tidak ditemukan adanya usulan atau pun pembahasan mengenai bank sentral. Pembahasan yang mengemuka saat itu lebih banyak terkait dengan hal keuangan dan anggaran negara serta perekonimian dan kesejahteraan sosial secara umum.

Namun demikian, dalam penjelasan UUD 1945 yang dibuat kemudian, dan untuk pertama kali diumumkan dalam berita Republik pada tahun 1946, termuat keterangan mengenai bank sentral ini.

\footnotetext{
${ }^{18}$ Ibid hlm 191

19 Lester V Chandler, Benjamin Strong Central Bankers (Washinton: Brooking Institutition, 1958) hlm 4
} 
Penjelasan UUD 1945 semula tidak dimaksudkan sebagai penjelasan UUD 1945 yang bersifat resmi. Penjelasan ini dibuat oleh Soepomo untuk kepentingan sosialisasi dalam Berita Republik tahun 1946 itu, judulya ditulis dengan kata tentang yaitu penjelasan tentang undangundang dasar Negara Republik Indonesia, bukan penjelasan undang-undang dasar Negara Republik Indonesia sebagai nama dokumen. $^{20}$

Dalam penjelasan tentang UUD 1945 yang kemudian diberlakukan oleh Dekrit Presiden 5 Juli 1959 sebagai bagian tak terpisahkan dari naskah asli UUD 1945, dinyatakan, "juga tentang hal macam dan harga mata uang ditetapkan dengan undang-undang. Ini penting karena kedudukan uang itu besar pengaruhnya atas masyarakat. Oleh karena itu, keadaan uang itu harus ditetapkan dengan undang-undang. Berhubungan dengan itu, kedudukan Bank Indonesia yang mengeluarkna dan mengatur peredaran uang kertas ditetapkan dengan undang-undang. ${ }^{21}$

Dalam penjelasan Pasal 23 UUD 1945 tersebut, jelas dikatakan bahwa "kedudukan Bank Indonesia yang akan mengeluarkan dan mengatur peredaran uang kerta, ditetapkan dengan undang- undang”. Artinya eksistensi konstitusionalitas BI sebagai nama dan sebagai institusi bank sentral sudah terang benderang.

Sayangnya, ketentuan ini hanya terdapat di dalam penjelasan, yang meskipun sudah diberlakukan sebagai bagian dari UUD 1945 berdasarkan Dekrit Presiden 5 Juli 1959, tetapi tetap tidak bersifat normatif secara langsung oleh sebab itu, sebelum undang-undang tentang BI itu disusun, atas kebutuhan ketika itu, maka Bank Negara Indonesia Tahu 1946 yang dibentuk lebih dulu merupakan bank komersial yang meneruskan peranan de javasche Bank di zaman Hindia Belanda, juga diberi kedudukan untuk sementara sebagai bank sentral atau bank yang melaksanakan tugas BI sebagai bank sentral. ${ }^{22}$

Tentu hal tersebut masih perlu diteliti, apakah yang dimaksudkan di sini adalah "bank Indonesia" sebagai nama atau dalam pengertian gagasan tentang bank Indonesia. Sangat boleh jadi bahwa yang dimaksud dengan BI ketika itu adalah Bank Negara Indonesia (BNI) yang didirikan pada bulan Agustus 1946 yang pada awal berdirinya memang berfungsi sebagai bank sentral dalam sirkulasi uang

\footnotetext{
22 Jimly Asshiddiqqie, Komentar Atas UndangUndang Dasar Negara Republik Indonesia Tahun 1945, (Jakarta: SinarGrafika, 2009) hlm 88

${ }^{20}$ Thamrin Abdulllah dan Francis Tantri, Bank dan Lembaga Keuangan Bank, ( Jakarta: Rajawali Press, 2012) hlm 35-37

${ }^{21}$ Ibid hlm 27
} 
dan fungsi-fungsi lain dari bank sentral negara yang baru merdeka. ${ }^{23}$

Dengan demikian, “ bank Indonesia” yang disebutkan dalam penjelasan UUD 1945, dapat dipahami, bukan dimaksudkan sebagai nama, melainkan hanya konsep umum tentang bank sentral yang kemudian diwujudkan dengan dibentuknya Bank Negara Indonesia Tahun 1946.

Apalagi, terbukti bahwa dalam pembahasan dalam rapat-rapat BPUPKI dan PPKI tidak terdapat informasi mengenai pernah tidaknya soal bank sentral yang bernama BI itu didiskusikan, lebih-lebih lagi, penjelasan UUD 1945 itu sendiri disusun pada waktu yang hampir bersamaan dengan proses pembentukan Bank Negara Indonesia Tahun 1946, sehingga mudah ditafsirkan bahwa pembentukan BNI 1946 itu adalah dalam rangka merealisasikan gagasan pembentukan bank Indonesia yang sudah disebutkan di dalam penjelasan UUD 1945 itu. $^{24}$

Namun, demikian, meskipun kenyataan ini justru dapat memperkuat argumen pertama tersebut di atas, tetapi dapat pula ditafsirkan bahwa memang dikandung maksud bahwa bank sentral

\footnotetext{
${ }^{23}$ Ibid hlm 88

${ }^{24}$ Soedradjad Djiwandono, Paul Soetopo, Sukarwan dkk, Sejarah Bank Indonesia Periode IV: 1966-1983 Bank Indonesia pada Masa Stabilisasi, Rehabilitasi, dan Pembangunan Ekonom,(Bank Indonesia: Jakarta, 2006) hlm 7
}

Indonesia itu kelak disebut $\mathrm{BI}$, atau bahwa BI yang disebut-sebut dalam penjelasan UUD 1945 kelak akan berfungsi sebagai bank sentral. Sedangkan Bank Negara Indonesia sebagai bank komersial, yang karena kebutuhan untuk tahap pertama diberikan kedudukan dan peranan sebagai bank sentral, disamping bank komersial.

Selanjutnya, dalam Konstitusi RIS yang dibuat sebagai konsekuensi hasil perjanjian Konferensi Meja Bundar antara RI dan Belanda pada tahun 1949 yang melahirkan RIS, rumusan mengenai bank sentral termuat dalam satu ayat dan diberi nama bank sirkulasi. Rumusan tersebut terdapat dalam $\mathrm{BAB}$ IV tentang pemerintahan, pada bagian 4 tentang Keuangan, yaitu pada Pasal 165 yang berbunyi. (1) “ untuk Indonesia ada satu bank sirkulasi" dan (2) " penudjukan sebagai bank sirkulasi dan pengaturan tataan dan kekuasaan dilakukan dengan undang-undang federal. ${ }^{25}$

Selanjutnya, pengaturan mengenai bank sentral dalam UUDS 1950 terdiri atas tiga ayat yang terdapat dalam BAB IV tentang keuangan, yaitu pada Pasal 109 ayat (4), Pasal 110 ayat (1), dan Pasal 110 ayat (2). Pasal 109 ayat (4) UUDS 1950 tersebut berbunyi “ pengeluaran alat-alat

\footnotetext{
${ }^{25}$ Soedradjad Djiwandono, Paul Soetopo, Sukarwan dkk, Sejarah Bank Indonesia Periode II: 1959-1966, Bank Indonesia Pada Masa Ekonomi Terpimpin, (Bank Indonesia: Jakarta, 2005) hlm 2
} 
pembayar yang sah dilakukan oleh atau atas naman pemerintah Republik Indonesia oleh bank sirkulasi”. Sedangkan Pasal 110 menentukan: (1) Untuk Indonesia ada satu bank sirkulasi; (2) Penunjukan sebagai bank sirkulasi dan pengaturan tataan dan kekuasaan dilakukan dengan undang-undang. ${ }^{26}$

Pasal 23D UUD 1945 menentukan, "Negara memiliki suatu bank sentral yang susunan, kedudukan, kewenangan, tanggung jawab, dan independensinya diatur dengan undang-undang". Ketentuan konstitusional tentang bank sentral ini memang hanya terdiri atas satu pasal dan ayat. Tetapi didalamnya, terkandung subtansi yang sangat mendasar. Jika kita meneelaah risalah pembahannya rancangan perumusan pasal ini, akan dapat diketahui hal-hal sebagai berikut. Pertama, negara ditegaskan memiliki "suatu bank sentral". Suatu bank sentral itu menunjukan kepada satu lembaga yang berfungsi sebagai bank sentral dengan nama yang tidak ditentukan secara eksplisit. Nama Bank Indonesia itu diwarisi dari sejarah dan kemudian dikukuhkan dalam pelbagai undangundang, terakhir dengan Undang-Undang Nomor 6 Tahun 2009 tentang Bank Indonesia.
Kedua, bank sentral dimaksudkan itu mempunyai susunan dan kewenangan, tanggung jawab, dan kedudukan yang independen. Ketentuan mengenai susunan, kewenangan, tanggung jawab, dan indepedensinya itu akan diatur lebih lanjut dengan undang-undang. Undang-undang dimaksud dewasa ini telah ditetapkan, yaitu dengan Undang-Undang Nomor 23 Tahun 1999 tentang Bank Indonesia sebagaimana telah diubah dengan Undang-Undnag Nomor 2 Tahun 2008 dan Undang-Undang Nomor 6 Tahun 2009.

Mengenai nama dan independensi bank sentral ini, dalam rapat-rapat $\mathrm{PAH}$ BP MPR 2001-2002, telah diperdebatkan panjang lebar dan dengan sangat mendalam. Bahkan, dimuat tidaknya ketentuan mengenai bank sentral ini juga menjadi salah satu topik yang hangat diperdebatkan. Semula, muncul keinginan untuk menentukan secara tegas kedudukan bank sentral yang bersifat mandiri dan bahwa bank sentral dimaksud adalah BI. Perdebatan mengenai penyebutan secara eksplisit nama Bidan prinsip independensi bank sentral ini diwarnai oleh kenyataan sangat independennya BI pasca reformasi yang atas prakarsa Presiden BJ Habibie menikmati kedudukan yang tidak tersentuh. $^{27}$

\footnotetext{
${ }^{27}$ Ibid hlm 88
}

\footnotetext{
26 Jimly Asshiddiqqie, Konstitusi Ekonomi, (Jakarta: Kompas, 2016) hlm 226-231
} 


\begin{abstract}
Presiden Habibie sendiri
mengumumkan kebijakannya yang

menentukan status BI sebagai lembaga

independen dari campur tangan

pemerintah. Pengumuman itu dilakukan oleh Presiden BJ Habibie pada 21 Mei 1998, sehari sesudah menjabat sebagai presiden, bersamaan dengan pengumuman kabinet reformasi. Gubenur Bank Indonesia yang pada masa orde baru selalu diberi kedududkan sebagai anggota kabinet, dibebaskan oleh Presiden BJ Habibie untuk tidak lagi berstatus sebagai anggota kabinet dan karenanya tidak lagi diharuskan mengikuti sidang-sidang kabinet. $^{28}$
\end{abstract}

Kebijakan independensi BI itu, kemudian lebih dikukuhkan lagi dengan Undang-Undang Nomor 23 Tahun 1999 tentang Bank Indonesia. Namun demikian, independensi bank sentral ini dalam pelaksanaannya kemudian dianggap telah berkembang menjadi kebablasan. Bahkan ketika presiden Abdurrahman Wahid bermaksud mengganti Syahril Sabirin dari jabatannya sebagai gubenur, presiden tidak berdaya dan tidak dapat melaksanakan niatnya karena ketentuan independensi bank sentral yang demikian kuat. Kasus rencana pemberhentian paksa terhadap Gubenur Syahril Sabirin itu, disatu pihak dianggap sebagai contoh

\footnotetext{
${ }^{28} \mathrm{Ibid}$ hlm 88
}

keberhasilan dari status independensinya bank itu, tetapi di pihak lain banyak pula yang menanggapi sebagai kebablasan.

Karena itu, suasana pembahasan rancangan Pasal 23D perubahan keempat UUD 1945 pada tahun 2002 sangat diwarnai oleh pro-kontra mengenai status independensi BI, bahkan ketika itu juga muncul pandangan yang ingin memisahkan antra fungsi policy making dengan fungsi pengawasan. BI dianggap terlalu berkuasa dipandanng perlu dipisahkan dari tanggung jawab pengawasan yang hendak dilembagakan tersendiri dengan nama OJK atau Otoritas Jasa Keuangan.

Perumusan mengenai susunan, kedudukan, kewenangan, tanggung jawab, dan terutama mengenai independensi bank sentral itu juga diperdebatkan dengan serius dalam rapat-rapat PAH I BP MPR sejak rapat ke-40 PAH I 7 Juni 2000. Semula, hampir semua fraksi mengusulkan pengaturan yang bersifat rinci. Bahkan, Asnawi Latief dari Fraksi Partai Daulat Ummat (PDU), mengusulkan pengaturan bank sentral itu dalam bab tersendiri yang terdiri atas 5 ayat, yaitu: ${ }^{29}$

1. Diseluruh Negara Kesatuan Republik Indonesia berlaku mata

\footnotetext{
${ }^{29}$ Sutjipno, Perubahan UUD 1945 tahun 1999-2002, (Jakarta: KonPress, 2010) hlm 138
} 
uang rupiah sebagai alat

pembayaran yang sah;

2. Mata uang rupiah dikeluarkan dan diedarkan oleh Bank Indonesia sebagai bank sentral;

3. Dalam pengeluaran dan mengatur peredaran uang, Bank Indonesia wajib memperhatikan pencapaian dan pemeliharaan stabilitas nilai rupiah;

4. Bank Indonesia sebagai bank sentral harus independen (mandiri) dan bebas dari campur tangan pemerintah atau pihakpihak lain;

5. Kedudukan dan pengaturan lebih lanjut tentang Bank Indonesia ditetapkan dengan undangundang

Dalam rangka membatasi kekuasaan itu, di zaman sekarang berkembang pula adanya pengaturan kelembagaan pemerintahan yang bersifat independen, seperti bank sentral, organisasi tentara, organisasi kepolisian. Lembaga, badang atau organisasi-organisasi ini sebelumnya dianggap sepenuhnya berada dalam kekuasaan eksekutif, tetapi sekarang berkembang menjadi independen sehingga tidak lagi sepenuhnya merupakan hak mutlak seorang kepala eksekutif untuk menentukan pengangkatan ataupun pemberhentian pimpinannya.

Independensi lembaga atau organ-organ tersebut dianggap penting untuk menjamin demokrasi, karena fungsinya dapat disalahgunakan oleh pemerintah untuk melanggengkan kekuasaan. Misalnya bank sentral dapat dimanfaatkan untuk mengontrol sumber-sumber keuangan yang dapat dipakai untuk tujuan mempertahankan kekuasaaan. ${ }^{30}$

\section{Dasar Pembentukan dan Kewenangan}

\section{Bank Indonesia}

Tabel dibawah ini mencoba memberikan gambaran kepada pembaca secara umum mengenai pengaturan mengenai bank sentral yang pernah ada di Indonesia dalam periodesasi konstitusi yang pernah berlaku di Indonesia, berikut juga mencoba menjabarkan aturan turunan yaitu undang-undang yang memberikan gambaran lebih lanjut mengenai kelembagaan bank sentral tersebut.

Tabel 1.1. Pengaturan Bank Sentral dalam berbagai Konstitusi di Indonesia ${ }^{31}$

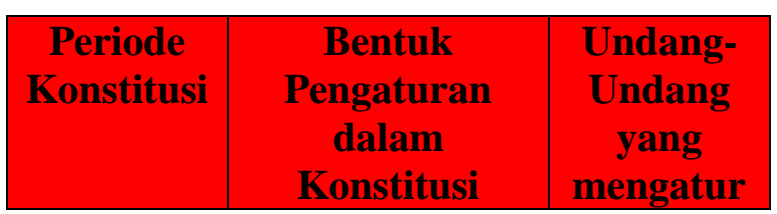

30 Jimly Asshiddiqqie, Konstitusi \& Konstitusionalisme Indonesia,(Jakarta: KonPress, 2008) hlm 156-157

31 Data diolah oleh Penulis untuk kepentingan penelitian ini yang bersumber dari Undang-Undang Dasar dan aturan turunan yang ada dan dapat diakses. 


\begin{tabular}{|c|c|c|}
\hline $\begin{array}{l}\text { UUD } 1945 \\
\text { sebelum } \\
\text { perubahan }\end{array}$ & Tidak ada & $\begin{array}{l}\text { Undang- } \\
\text { Undang } \\
\text { Nomor } 24 \\
\text { Tahun } \\
1951 \\
\text { tentang } \\
\text { Nasionalis } \\
\text { asi De } \\
\text { Javasche } \\
\text { Bank N.V }\end{array}$ \\
\hline $\begin{array}{l}\text { Konstitusi } \\
\text { RIS }\end{array}$ & $\begin{array}{l}\text { Pasal } 165 \text { (1) } \\
\text { Untuk Indonesia } \\
\text { ada satu bank } \\
\text { sirkulasi }\end{array}$ & \\
\hline $\begin{array}{l}\text { UUDS } \\
1950\end{array}$ & $\begin{array}{l}\text { Pasal } 109 \text { ayat } \\
\text { (4) } \\
\text { Pengeluaran } \\
\text { alat-alat } \\
\text { pembajar jang } \\
\text { sah dilakukan } \\
\text { oleh atau atas } \\
\text { nama } \\
\text { pemerintah } \\
\text { Republik } \\
\text { Indonesia oleh } \\
\text { bank sirkulasi } \\
\text { Pasal 110 } \\
\text { 1. Untuk } \\
\text { Indonesia ada } \\
\text { satu Bank } \\
\text { Sirkulasi } \\
\text { 2. Penudjuk } \\
\text { an sebagai } \\
\text { Bank Sirkulasi } \\
\text { dan pengaturan } \\
\text { tatan dan } \\
\text { kekuasaannja } \\
\text { dilakukan } \\
\text { dengan } \\
\text { undang- } \\
\text { undang }\end{array}$ & $\begin{array}{l}\text { Undang- } \\
\text { Undang } \\
\text { Nomor } 11 \\
\text { Tahun } \\
1953 \\
\text { tentang } \\
\text { Pokok- } \\
\text { Pokok } \\
\text { Bank } \\
\text { Indonesia }\end{array}$ \\
\hline $\begin{array}{l}\text { Kembali } \\
\text { ke UUD } \\
1945\end{array}$ & Tidak ada & $\begin{array}{l}\text { Undang- } \\
\text { Undang } \\
\text { Nomor } 13 \\
\text { Tahun } \\
1968 \\
\text { tentang } \\
\text { Bank } \\
\text { Sentral }\end{array}$ \\
\hline
\end{tabular}

\begin{tabular}{|c|c|c|}
\hline $\begin{array}{l}\text { UUD } \\
\text { setelah } \\
\text { perubahan }\end{array}$ & $\begin{array}{l}\text { Pasal 23 D } \\
\text { Negara memiliki } \\
\text { suatu bank } \\
\text { sentral yang } \\
\text { susunan, } \\
\text { kedudukan, } \\
\text { kewenangan, } \\
\text { tanggung jawab, } \\
\text { dan } \\
\text { independensinya } \\
\text { diatur dengan } \\
\text { undang-undang }\end{array}$ & $\begin{array}{l}\text { Undang- } \\
\text { Undang } \\
\text { Nomor } 23 \\
\text { Tahun } \\
1999 \text {, } \\
\text { Undang- } \\
\text { undang } \\
\text { Nomor } 3 \\
\text { Tahun } \\
\text { 2004, } \\
\text { Undang- } \\
\text { Undang } \\
\text { Nomor } 2 \\
\text { Tahun } \\
\text { 2008 dan } \\
\text { Undang- } \\
\text { Undang } \\
\text { Nomor } 6 \\
\text { Tahun } \\
\text { 2009 }\end{array}$ \\
\hline
\end{tabular}

memberikan penjelasan mengenai politik hukum pengaturan bank sentral yang pernah ada di Indonesia, dimana dalam UUD 1945 sebelum perubahan sama sekali tidak memiliki kelembagaan bank sentral namun Konstitusi RIS, UUDS 1950 dan UUD 1945 setelah perubahan telah menempatkan adanya pengaturan mengenai lembaga bank sentral sebagai organ negara. Selanjutnya penulis mengupas mengenai tugas yang ada pada bank sentral dalam 2 (dua) undangundang. Adapun tugas Bank Indonesia menurut 2 (dua) Undang-Undang tentang Bank Sentral adalah sebagai berikut: 
Tabel 1.2 Tugas dan Wewenang Bank

\section{Indonesia menurut 2 (dua) Undang-}

Undang $^{32}$

\begin{tabular}{|c|c|c|}
\hline No & $\begin{array}{l}\text { Undang- } \\
\text { Undang Nomor } \\
13 \text { Tahun } 1968\end{array}$ & $\begin{array}{l}\text { Undang-Undang } \\
\text { Nomor } 23 \text { Tahun } \\
1999\end{array}$ \\
\hline 1 & $\begin{array}{l}\text { Tugas pokok } \\
\text { Bank adalah } \\
\text { membantu } \\
\text { Pemerintah } \\
\text { dalam: } \\
\text { 1. Mengatur, } \\
\text { mendjaga dan } \\
\text { memelihara } \\
\text { kestabilan } \\
\text { nilai Rupiah; } \\
\text { 2. Mendorong } \\
\text { kelantjaran } \\
\text { produksi dan } \\
\text { pembangunan } \\
\text { serta } \\
\text { memperluas } \\
\text { kesempatan } \\
\text { kerja guna } \\
\text { meningkatkan } \\
\text { taraf hidup } \\
\text { rakjat } \\
\text { (didalam BAB IV } \\
\text { Pasal } 7 \text { UU No } \\
\text { 13 Tahun 1968) }\end{array}$ & $\begin{array}{l}\text { Tujuan Bank } \\
\text { Indonesia adalah } \\
\text { mencapai dan } \\
\text { memelihara } \\
\text { kestabilan nilai } \\
\text { rupiah } \\
\text { (didalam Pasal } 7 \\
\text { UU No 23 Tahun } \\
\text { 2003) } \\
\text { Untuk mencapai } \\
\text { tujuan } \\
\text { sebagaimana } \\
\text { dimaksud dalam } \\
\text { Pasal } 7 \text {, Bank } \\
\text { Indonesia } \\
\text { mempunyai tugas } \\
\text { sebagai berikut: } \\
\text { 1. Menetapkan } \\
\quad \text { dan } \\
\text { melaksanakan } \\
\text { kebijakan } \\
\text { moneter } \\
\text { 2. Mengatur dan } \\
\text { menjaga } \\
\text { kelancaran } \\
\text { sistem } \\
\text { pembayaran } \\
\text { 3. Mengatur dan } \\
\text { mengawasi } \\
\text { Bank } \\
\text { (didalam Pasal } 8 \\
\text { UU No 23 Tahun } \\
\text { 1999) }\end{array}$ \\
\hline
\end{tabular}

${ }^{32}$ Data diolah oleh Penulis dari peraturan perundangundangan yang ada untuk dianalisa sesuai dengan kebutuhan penulisan makalah ini
Dari pengkajian pasal-pasal dalam kedua UU tersebut maka dapat disimpulkan bahwa dalam perubahannya BI telah di transformasi tidak hanya yaitu tidak lagi bertanggung jawab terhadap kelancaran produksi dan pembangunan yang seyogyanya merupakan tupoksi tugas wajib pemerintah namun BI dalam perkembangannya memiliki kewenangan yang lebih kepada bidang moneter saja. Sehingga dengan adanya perubahan tugas ini maka BI dapat lebih fokus menjalankan kewajibannya dan tidak ada lagi tumpang tindih (overlapping) tugas dengan pemerintah. Langkah ini merupakan usaha untuk membuat BI lebih independen dalam menjalankan tugasnya sehingga tidak ada lagi titik singgung yang dapat menyebabkan adanya intervensi pemerintah kepada BI.

4. Model Pengisian Jabatan dan Anggaran Kelembagaan

Perbandingan Pengisisan Jabatan Publik Pimpinan Bank Indonesia menurut Undang-Undang Nomor 13 Tahun 1968 dan Undang-Undang Nomor 23 Tahun 1999

Tabel 1.3 Pengaturan Mengenai Pengisian Jabatan di Bank Indonesia ${ }^{33}$

\begin{tabular}{|l|l|l|}
\hline No & $\begin{array}{l}\text { Undang- } \\
\text { Undang Nomor } \\
\text { 13 Tahun 1968 }\end{array}$ & $\begin{array}{l}\text { Undang-Undang } \\
\text { Nomor 23 Tahun } \\
1999\end{array}$ \\
\hline
\end{tabular}

33 Data diolah oleh penulis berdasarkan peraturan perundang-undangan yang ada gunak kebutuhan penulisan makalah ini 


\begin{tabular}{|c|c|c|c|c|}
\hline $\begin{array}{l}\text { 1. Dewan } \\
\text { Moneter } \\
\text { membantu } \\
\text { Pemerintah } \\
\text { dalam } \\
\text { merentjanakan } \\
\text { dan } \\
\text { menetapkan } \\
\text { kebidjaksanaa } \\
\text { n moneter } \\
\text { seperti } \\
\text { termaksud } \\
\text { dalam Pasal } 8 \text {, } \\
\text { dengan } \\
\text { mengadjukan } \\
\text { patokan- } \\
\text { patokan dalam } \\
\text { rangka usaha } \\
\text { mendjaga } \\
\text { kestabilan } \\
\text { moneter, } \\
\text { kepenuhan } \\
\text { kesempatan } \\
\text { kerdja dan } \\
\text { peningkatan } \\
\text { mutu taraf } \\
\text { hidup rakjat. } \\
\text { 2. Dewan } \\
\text { Moneter } \\
\text { memimpin } \\
\text { dan } \\
\text { mengkoordini } \\
\text { r pelaksanaan } \\
\text { kebidjaksanaa } \\
\text { n moneter } \\
\text { jang telah } \\
\text { ditetapkan } \\
\text { pemerintah } \\
\text { (didalam Pasal } \\
\text { 9 ayat (1) (2) } \\
\text { UU No } \\
\text { Tahun 1968) }\end{array}$ & 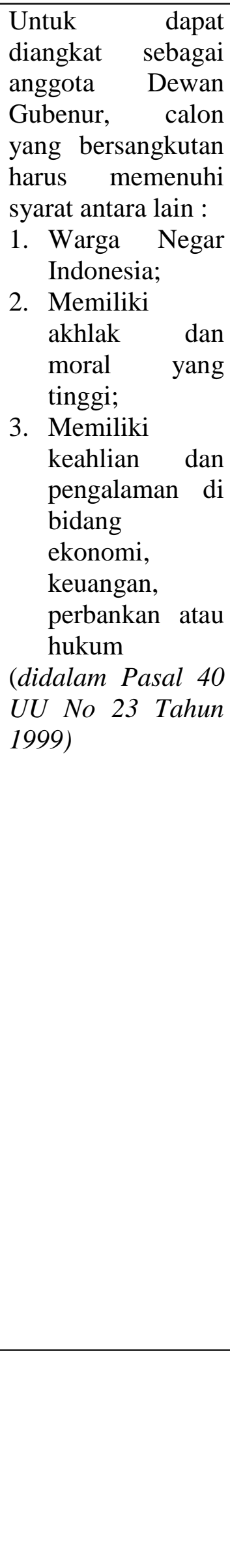 & 2 & $\begin{array}{l}\text { 1. Dewan } \\
\text { Moneter } \\
\text { terdiri atas } 3 \\
\text { (tiga) orang } \\
\text { anggota, jaitu } \\
\text { menteri- } \\
\text { menteri jang } \\
\text { membidangi } \\
\text { keuangan dan } \\
\text { perekonomian } \\
\text { dserta } \\
\text { Gubenur } \\
\text { Bank; } \\
\text { 2. Antara } \\
\text { Anggota- } \\
\text { anggota } \\
\text { Dewan } \\
\text { Moneter dan } \\
\text { Anggota- } \\
\text { anggota } \\
\text { direksi tidak } \\
\text { boleh ada } \\
\text { hubungan } \\
\text { keluarga } \\
\text { sampai } \\
\text { dengan } \\
\text { deradjat } \\
\text { ketiga } \\
\text { menurut garis } \\
\text { lurus maupun } \\
\text { garis } \\
\text { kesamping } \\
\text { termasuk } \\
\text { menantu dan } \\
\text { ipar } \\
\text { 3. jika seorang } \\
\text { Anggota } \\
\text { Direksi } \\
\text { sesudah } \\
\text { pengankatann } \\
\text { nja masuk } \\
\text { hubungan } \\
\text { keluarga jang } \\
\text { terlarang } \\
\text { dengan } \\
\text { seorang } \\
\text { Anggota } \\
\text { Dewan } \\
\text { Moneter } \\
\text { sebagai }\end{array}$ & 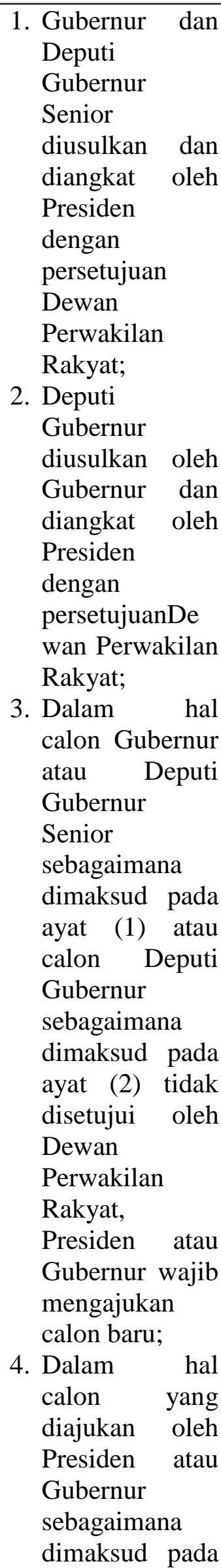 \\
\hline
\end{tabular}




\begin{tabular}{|c|c|}
\hline $\begin{array}{l}\text { dimaksudkan } \\
\text { dalam ajat (2), } \\
\text { maka Anggota } \\
\text { direksi jang } \\
\text { bersangkutan } \\
\text { tidak boleh } \\
\text { terus } \\
\text { memangku } \\
\text { djabtannja } \\
\text { tanpa izin } \\
\text { Presiden. } \\
\text { 4. Dijika } \\
\text { dipandang } \\
\text { perlu, } \\
\text { Pemerintah } \\
\text { dapat } \\
\text { menambahkan } \\
\text { beberapa } \\
\text { orang Menteri } \\
\text { sebagai } \\
\text { Anggota } \\
\text { penasehat } \\
\text { kepada } \\
\text { Dewan } \\
\text { Moneter } \\
\text { 5. Sekretariat } \\
\text { Dewan } \\
\text { Moneter } \\
\text { diselenggarak } \\
\text { an oleh } \\
\text { Departemen } \\
\text { Keuangan } \\
\text { (didalam Pasal } \\
\text { 10 } \\
\text { (1)(2)(3)(4)(5) } \\
\text { UU No } 13 \\
\text { Tahun 1968) }\end{array}$ & 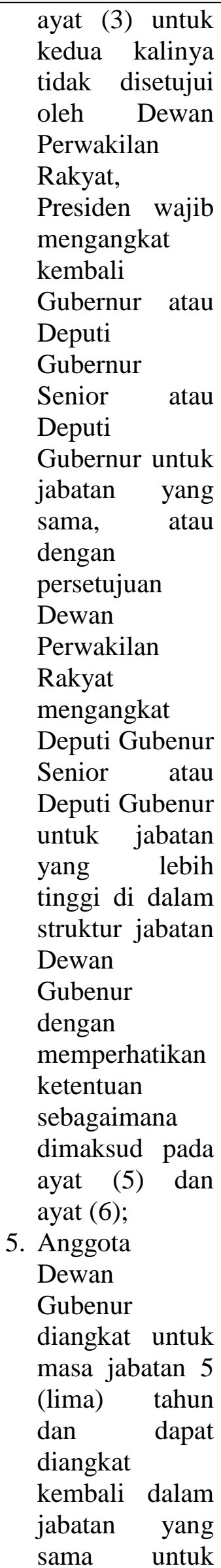 \\
\hline
\end{tabular}

\begin{tabular}{|l|l|}
\hline sebanyak- \\
banyaknya 1 \\
(satu) kali masa \\
jabatan \\
berikutnya \\
6. Penggantian \\
anggota Dewan \\
Gubenur yang \\
telah berakhir \\
masa \\
jabatannya \\
dilakukan \\
secara berkala \\
setiap tahun \\
paling banyak 2 \\
(dua) orang. \\
(didalam Pasal 41 \\
ayat (1)(2)(3)(4) \\
UU No 23 Tahun \\
1999)
\end{tabular}

Tabel 1.4 Pengaturan tentang Anggaran Bank Indonesia ${ }^{34}$

\begin{tabular}{|l|l|l|}
\hline No & $\begin{array}{l}\text { Undang- } \\
\text { Undang Nomor } \\
\text { 13 Tahun 1968 }\end{array}$ & $\begin{array}{l}\text { Undang- } \\
\text { Undang Nomor } \\
\text { 23 Tahun 1999 }\end{array}$ \\
\hline
\end{tabular}

\begin{tabular}{|c|c|c|}
\hline 1 & $\begin{array}{l}\text { 1. Sebelum } \\
\text { tahun buku } \\
\text { baru mulai } \\
\text { berjalan, } \\
\text { direksi } \\
\text { menyampaik } \\
\text { an Anggaran } \\
\text { Tahunan } \\
\text { Bank kepada } \\
\text { Pemerintah } \\
\text { untuk } \\
\text { disetujui } \\
\text { 2. Persetujuan } \\
\text { Pemerintah } \\
\text { atas } \\
\text { Anggaran } \\
\text { Tahun Bank }\end{array}$ & $\begin{array}{l}\text { 1. Tahun } \\
\text { anggaran } \\
\text { Bank } \\
\text { Indonesia } \\
\text { adalah tahun } \\
\text { kalender } \\
\text { 2. Selambat- } \\
\text { lambat 15 } \\
\text { (lima belas) } \\
\text { sebelum } \\
\text { dimulai } \\
\text { tahun } \\
\text { anggaran, } \\
\text { Dewan } \\
\text { Gubenur } \\
\text { menetapkan } \\
\text { anggaran }\end{array}$ \\
\hline
\end{tabular}

34 Data diolah oleh penulis berdasarkan peraturan perundang-undangan yang ada gunak kebutuhan penulisan makalah ini 


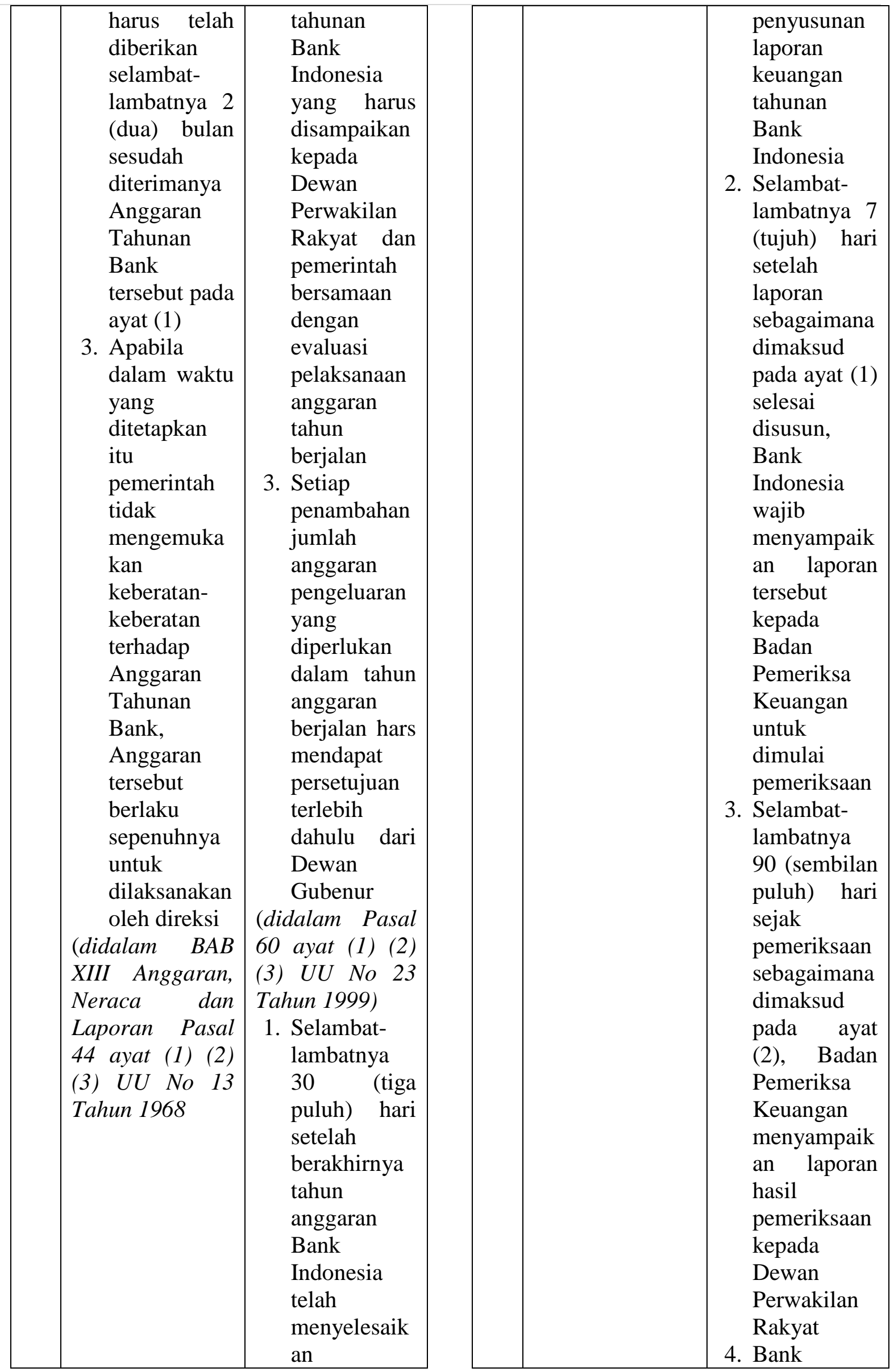




\begin{tabular}{|l|l|}
\hline $\mid$ & Indonesia \\
wajib \\
mengumumk \\
an laporan \\
keuangan \\
tahunan \\
Bank \\
Indonesia \\
kepada \\
publik \\
melalui \\
media \\
massa. \\
\\
\\
(didalam Pasal \\
61 ayat (1) (2) \\
(3) (4) UU No \\
23 Tahun 1999)
\end{tabular}

\section{Konsep Kemandirian Lembaga Bank} Indonesia

Menurut Fabian Amtenbrink ada beberapa teori yang dapat digunakan untuk mengukur independensi atau kemandirian bank sentral yaitu: independensi institusi, fungsi, organisasi, dan keuangan. Lebih lanjut sebagai berikut: ${ }^{35}$

\section{1) Kemandirian institusi (institutional independence)}

Pada umumnya, independensi institusi bank sentral diartikan sebagai status bank sentral yang secara institusi terpisah dari kekuasaan eksekutif (pemerintah) dan kewenangan legislatif (parlemen). Dapat dikatakan bahwa suatu bank sentral yang merupakan bagian dari pemerintah, misalnya sebagai bagian dari

\footnotetext{
${ }^{35}$ Maqdir Ismail, Bank Indonesia dalam Perdebatan Politik dan Hukum, (Yogyakarta: Navila Idea, 2005) hlm 71
}

departemen keuangan (treasury), akan kehilangan kemandirian sebagai suatu institusi. Dalam hal ini, legal basis bagi bank sentral dan posisinya dalam sistem konstitusional negara yang bersangkutan memegang peranan yang pentig. Terkait dengan tugas bank sentral, institutional independence diartikan sbaai kewenangan bank sentral untuk menetapkan kebijakan moneter secara independen dan bebas dari pengaruh institusi politik, khususnya dari eksekutif pemerintahan.

\section{2) Kemandirian Fungsi (Functional Independence)}

Suatu bank sentral dinilai memiliki kemandirian fungsi apabila mempunyai kebebasan dalam menggunakan instrumen-instrumen kebijakan moneter, seperti penyesuaian tingkat suku bunga dan operasi pasar terbuka. Dalam konteks ini, kemandirian fungsi diartikan juga sebagai kemandirian instrumen yang menggambarkan suatu bank sentral memiliki kebebasan memilih instrumen yang diperlukan untuk mencapai tujuannya Kemandiran fungsi dianggap dibatasi apabila dalam tindakan yang diambil oleh bank sentral didahului dengan adanya otorisasi dari pemerintah atau apabila eksekutif pemerintahan mempengaruhi keputusan yang diambil oleh bank sentral. Kemandirian fungsi dari suatu bank sentral juga melarang adanya kewajiban untuk memberikan cerukan dan 
fasilitas kredit lainnya kepada pemerintah.

\section{3) Kemandirian}

organisasi

\section{(organization independence)}

Kemandirian

organisasi

berhubungan dengan komposisi personalia dari organ-organ yang ada di bank sentral dan sistem pengangkatan dan pemberhentian karyawan-karyawan bank sentral. Beberapa penelitian memfokuskan pada komposisi dewan pengambil kebijakan (Dewan Gubenur) di bank sentral. Di sini, hal yang memperoleh perhatian adalah partisipasi/ peranan pejabat-pejabat pemerintah terhadap Dewa Gubenur bank sentral. Memang, tidak dapat dihindari bahwa sistem bank sentral yang memberikan voting kepada pejabat-pejabat pemerintah atas kebijakan board yang cenderung membuka peluang bagi timbulnya campur tangan pemerintah, dalam hal ini kemandirian organisasi juga mengacu pada kemandirian para pejabat bank sentral dari pengaruh institusi pemerintah

4) Kemandirian Finansial (financial independence)

Kemandirian finansial mengacu pada peranan pemerintah dan/atau parlemen terhadap anggaran bank sentral. Dalam hal ini, apabila terdapat kontrol oleh pemerintah atas anggaran bank sentral, maka bank sentral tersebut akan rentan terhadap tekanan politik, khususnya yang berkaitan dengan kebijakan moneter yang diambil. Oleh karena itu, dalam rangka mengamankan independensi bank sentral dari pengaruh pemerintah, disarankan agar bank sentral mempunyai anggaran sendiri yang terlepas dari persetujuan pemerintah. Umumnya bank sentral dapat mengamankan aset finansial agar independen, anatra lain melalui penerbitan bank notes dan open market operation. Selain itu, cara redistribusi keuntungan juga dapat dilakukan sebagai kriteria untuk menetapkan tingkat independensi bank sentral. Dalam hal ini, suatu bank sentral dikatakan independen bila memiliki kebebasan dalam menggunakan keuntungan yang diperolehnya.

Dalam undang-undang Bank Indonesia, independensi di bidang anggaran terlihat dalam ketentuan Pasal 60 yang menyatakan bahwa anggaran Bank Indonesia ditetapkan oleh Dewan Gubenur. Ketentuan ini adalah konsekuensi dari status Bank Indonesia sebagai badan hukum, sebagai badan hukum, Bank Indonesia mempunyai wewenang mengelola kekayaannya sendiri terlepas dari Anggaran Pendapatan dan Belanja Negara. Berbeda dengan Rencana Anggaran Pendapatan dan Belanja negara yang ditetapkan dengan undang-undang karena sebagian besar danannya berasal dari rakyat berupa pajak. Sedangkan anggaran Bank 
Indonesia berasal dari kegiatan usahanya sebagai sebagai bank sentral. ${ }^{36}$

Mekanisme voting yang dilakukan oleh DPR (komisi) seakan mekanisme seleksi pimpinan BI layaknya pemilihan umum. Yang mana kandidat adalah calon pimpinan Bank Indonesia dan konstituen adalah anggota DPR. Dengan fakta tersebut, selain rentan praktik transaksional antara calon pimpinan Bank Indonesia yang bersifat materi, juga rentan terjadi praktik kandidatkandidat titipan mengingat posisi Bank Indonesia yang sangat strategis.

Kasus Miranda Swaray Goeltom merupakan bukti nyata dari mekanisme DPR sangat politis, transaksional dan menggangu independensi Bank Indonesia. Perbedaan penafsiran dari persetujuan oleh DPR sebagaimana yang dinyatakan dalam undangundang menjadi pemilihan oleh DPR dengan konsep one man one vote oleh DPR adalah fakta hukum yang secara tegas dapat menganggu independensi Bank Indonesia. Sebagai perbandingan nyata, bahasa, "persetujuan oleh DPR" juga ditemukan dalam proses seleksi hakim agung yang sebelum adanya putusan Mahkamah Konstitusi Nomor 27/PUU-XI/2013, mekanisme "persetujuan oleh DPR" dalam

\footnotetext{
${ }^{36}$ Dawan Rahardjo, Bank Indonesia Dalam Kilasan Sejarah Bangsa, (Jakarta:LP3ES, 1995) hlm 53
}

seleksi hakim agung juga dilaksanakan dengan cara pemilihan atau voting. ${ }^{37}$

Ketika gerakan reformasi berhasil menjebol tembok sakralisasi UUD 1945, banyak hal yang dikemukan oleh masyarakat, terutama kalangan akademisi, berkaitan dengan gagasan untuk memperbaiki UUD agar ia mampu membangun sistem politik dan ketatanegaraan yang demokratis. Gagasan ini menjadi niscaya karena selama berlakunya UUD 1945 dalam tiga periode sistem politik ternyata di Indonesia tak pernah lahir sistem politik yang demokratis sehingga selalu timbul korupsi dalam berbagai kehidupan ${ }^{38}$

Keterlibatan DPR dalam rekrutmen pejabat publik itu sebenarnya hanya varian saja dari fungsi pengawasan yang dimiliki oleh DPR sebagaimana ditentukan dalam UUD 1945. Dalam pratik di Amerika serikat, misalnya, hal itu dikaitkan dengan hak untuk memberikan konfirmasi atas pengangkatan pejabat publik tertentu oleh presiden (right to confirm) sebagai bagian dari fungsi pengawasan politik terhadap berjalannya proses pemerintahan. Namun, dalam praktik di Indonesia pengertian "right to confirm" itu cenderung menyimpang fungsinya yang

37 Nurul Fajri, Memperkuat Independensi Bank Indonesia Melalui Proses Seleksi Pimpinan Bank Indonesia dalam Pengisian Jabatan Pimpinan Lembaga Negara Independen Seri 3, (Jakarta: Rajawali Press, 2016) hlm 280-283

38 Moh Mahfud, Perdebatan Hukum Tata Negara Pascaamendemen Konstitusi (Jakarta: Rajawali Press, 2010) hlm 67 
bersifat politis menjadi sangat teknis. Dalam praktik " the right to confirm" itu berkembang menjadi " the right to elect" dan lebih teknis lagi menjadi "the right to select" dan bahkan menjadi " the right to test". 39

\section{Penutup}

Menata kembali kelembagaan dan independensi Bank Indonesia adalah Conditio Sine Qua non. Karena lembaga bank Indonesia adalah lembaga yang memegang peranan yang penting dalam bidang moneter. Bank Indonesia sebagai lembaga negara yang mandiri seharusnya memiliki pengaturan yang lebih lengkap sebagaimana pengaturan lembaga negara lainnya yang secara eksplisit sebagai kekuasaan yang independen. Oleh karena itu konstitusi harus menjamin pemilihan pimpinan bank sentral dilakukan secara transparan, akuntabel dan penuh integritas oleh karena itu seyogyanya pemilihan pimpinan Bank Indonesia haruslah jauh dari kepentingan politik pragmatis. Selain model pengisian yang perlu juga dipastikan adalah bahwa Bank Indonesia memiliki keluwesan dalam mengatur keuangan atau anggaran lembaganya sehingga tidak rentan untuk diintervensi oleh pemerintah dengan begitu maka Bank Indonesia dapat menjalankan tugasnya dengan lebih baik lagi.

\footnotetext{
${ }^{39}$ Jimly Asshiddiqqie, Liberalisasi Pengisian Jabatan Publik dalam Pengisian Jabatan Hakim Agung dan Hakim Konstitusi Seri 1, (Jakarta: Rajawali Press, 2016) hlm13
}

\section{Daftar Pustaka}

Abdy Yuhana, (2007) Sisem Ketatanegaran di Indonesia Pasca Peubahan UUD 1945, Bandung: Fokusmedia.

Akhand Akhtar Hossain, (2010) Bank Sentral dan Kebijakan Moneter di Asia Pasifik, Jakarta: Rajawali Press,.

Dawan Rahardjo, (1995) Bank Indonesia Dalam Kilasan Sejarah Bangsa, Jakarta:LP3ES.

Fachry Ali, Bahtiar Effendy, Umar Juoro dkk, (2003) The Politicis of Central Bank, The Position of Bank Indonesia Governor in Defending Independence, Jakarta: LSPEU Indonesia.

Hamdan Zoelva, (2007) Sistem Penyelenggaraan Kekuasaan Negara Menurut Undang-Undang Dasar Negara Republik Indonesia 1945 dalam perubahan UUD 1945 Tahun 1999-2002 ( dalam bahasa akademik, bukan politik), Jakarta: KonPress.

Hendra Nurtjahjo, (2002) Mustafa Fakhri, Fitra Arsil, Eksistensi Bank Sentral Dalam Konstitusi Beberapa Negara, Jakarta: Pusat Studi Hukum Tata Negara Fakultas Hukum Universitas Indonesia.

Herbert V Prochnow, (1990) The Federal Reserve System, (New York: Harper \& Brother Publisher.

Jimly Asshiddiqqie, (2009), Komentar Atas Undang-Undang Dasar Negara Republik Indonesia Tahun 1945, Jakarta: SinarGrafika.

Jimly Asshiddiqqie, (2016), Konstitusi Ekonomi, Jakarta: Kompas.

Jimly Asshiddiqqie, (2013), Pengantar Hukum Tata Negara, Jakarta: Rajawali Press. 
Jimly Asshiddiqqie, (2008), Konstitusi \& Konstitusionalisme Indonesia, Jakarta: KonPress.

Jimly Asshiddiqqie, (2016), Liberalisasi Pengisian Jabatan Publik dalam Pengisian Jabatan Hakim Agung dan Hakim Konstitusi Seri 1, Jakarta: Rajawali Press.

Kisch dan Elkin, (1928). Central Bank A Study of Constitution of Bank Issue, with analysis of Representative Charter, London: The Macmilan Company.

L.F Giblin, (1951), The Growth of A Central Bank, Melbourne: Melbourne University Press.

Lester V Chandler, (1958), Benjamin Strong Central Bankers, Washinton: Brooking Institutition.

Maqdir Ismail, (2005), Bank Indonesia dalam PerdeFbatan Politik dan Hukum, Yogyakarta: Navila Idea.

Moh Mahfud, (2001), Dasar dan Struktur Ketatanegaraan Indonesia Edisi Revisi, Jakarta:Rineka Cipta.

Moh Mahfud, (2010), Perdebatan Hukum Tata Negara Pascaamendemen Konstitusi,Jakarta: Rajawali Press.

Nurul Fajri, (2016), Memperkuat Independensi Bank Indonesia Melalui Proses Seleksi Pimpinan Bank Indonesia dalam Pengisian Jabatan Pimpinan Lembaga Negara Independen Seri 3, Jakarta: Rajawali Press.

Paul F Smith, (1982), Comparative Financial Systems, ( New York: Praeger Publisher.

Peter Hobday, (1976), Inside The Bank of England,Great Britain: Priory Press.

Phineas M Mojapelo, (2012), The Doctrine of Separation of Powers, a South
African Perspective), disampaikan dlaam The Middle Temple South Africa Conference.

Soedradjad Djiwandono, (2001), Mengelola Bank Indonesia Dalam Masa Krisis, (Jakarta: LP3ES.

Soedradjad Djiwandono, Paul Soetopo, Sukarwan dkk, (2006), Sejarah Bank Indonesia Periode IV: 1983-1997, Bank Indonesia pada Masa Pembangunan Ekonomi dan Pola Deregulasi, Bank Indonesia: Jakarta.

Soedradjad Djiwandono, Paul Soetopo, Sukarwan dkk, (2006), Sejarah Bank Indonesia Periode IV: 1966-1983 Bank Indonesia pada Masa Stabilisasi, Rehabilitasi, dan Pembangunan Ekonom, Bank Indonesia: Jakarta.

Soedradjad Djiwandono, Paul Soetopo, Sukarwan dkk, (2005), Sejarah Bank Indonesia Periode II: 1959-1966, Bank Indonesia Pada Masa Ekonomi Terpimpin, Bank Indonesia: Jakarta.

Sutjipno, (2010), Perubahan UUD 1945 tahun 1999-2002, Jakarta: KonPress/

Thamrin Abdulllah dan Francis Tantri, (2012), Bank dan Lembaga Keuangan Bank, Jakarta: Rajawali Press. 